\title{
Edible Insects a Novel Food Processing Industry: An Overview
}

Mukesh Nitharwal, Subhita Kumawat, Hanuman Singh Jatav, Mudassar Ahmed Khan, Kailash Chandra, Sanjay Kumar Attar, S.R. Dhaka

10.18805/ag.R-2357

\begin{abstract}
Humans are consuming roughly 40 per cent of the biomass that the land and the coastal seas produce is an alarming phase. The rate at which the population is increasing and demand of food reserves to provide nutritional food from the conventional protein production sources i.e. livestock, poultry and fish unable to keep up the supply. A concept behind edible insect farming has its roots from some of character i.e. high feed conversion efficiency, much less water and land requirement and less proven to diseases and higher portion to be utilizable (lack of bones) make insects a suitable source. Rearing and harvesting of the insect is a low tech, low-capital investment option even to poorest section of society, such as women and landless workers. Insects farming provide proteins at lowest cost of $40-75 \mathrm{~g}$ per $100 \mathrm{~g}$ of dry weight of insects.
\end{abstract}

Key words: Edible insects, Entomophagy, Insect farming, Novel food.

As human population is increasing at 70 million people per year and it's expected to be more than 9 billion by 2050 and food reserves are the lowest they have been in last 40 years (FAO, 2009). Humans are consuming roughly 40 per cent of the biomass that the land and the coastal seas produce is an alarming phase (Dzamba, 2010 and Safina, 2011). The rate at which the population is increasing and demand of food reserves to provide nutritional food from the conventional protein production sources i.e. livestock, poultry and fish unable to keep up the supply (van Huis, 2013). Need of protein supply for the increasing human population is burning issue, to obtain it from the sustainable environmental conditions is also challenge. Protein as an important dietary component, it cannot be underestimated. As proteins are the constituents of enzymes, transcription factors, antibodies, neurotransmitters, hormones and a whole lot of other vital body components. To meet the demand with sustainable environment, options like soybean, algae, insects, mycoproteins, among others, have been explored (Smetana et al. 2015).

A concept behind edible insect farming has its roots from the discussion and advocating the potential of edible insects from researchers around the world from last decades. Some of character i.e. high feed conversion efficiency, much less water and land requirement and less has proven to diseases and higher portion of edible parts (lack of bones) make insects a suitable source. The demand for livestock products will increase in two folds between 2000 and 2050 , the reason behind it is increasing request for meat by the population of developing countries. Livestock rearing is the one of the important factor responsible for 14 percent of the global greenhouse gas emissions (Gerber et al. 2013; Radhika and Subbaratnam, 2006) and they requires a remarkable land use. As the concept of vertical farming increasing, insect farmed plays an important role in this concept. Insect could offer economical and sustainable animal protein.
Sri Karan Narendra Agriculture University, Jobner-303 329, Jaipur, Rajasthan, India.

Corresponding Author: Mukesh Nitharwal, College of Agriculture, Fatehpur-Shekhawati, Sikar-302 301, Rajasthan, India.

Email: mukeshnitharwal.ento@sknau.ac.in

How to cite this article: Nitharwal, M., Kumawat, S., Jatav, H.S., Khan, M.A., Chandra, K., Attar, S.K. and Dhaka, S.R. (2022). Edible Insects a Novel Food Processing Industry: An Overview. Agricultural Reviews. DOI: 10.18805/ag.R-2357.

Submitted: 26-08-2021 Accepted: 24-12-2021 Online: 29-01-2022

Professor Gene DeFoliart, a forward looking medical entomologist, began to investigate the feed potential of edible insects for chicken in 1978 and he started the "The Food Insects Newsletter" in 1988. Researcher thinks that edible insects are environmentally sustainable, i.e. if insect farming is very close to environmental (green) technology which makes efficient use of natural resources while reducing/recycling wastes, to control the risks of chemical substances and to reduce pollution (Glavic and Lukman, 2007).

Insects are available in natural habitat, but they may be threatened natural resource when harvesting from nature, as overexploitation of limited resource, habitat destruction and pollution. In Mexico 14 species of edible insects are being under threatened and harvesting edible insects from nature in central Africa have some impact on ecosystem due to logging and bushfire diminish these insect populations. Overuse of pesticides and runoff to the waterways causes decline of some of edible insects found in the habitat, i.e. Water bug, Lethocerus indicus (Hemiptera: Belostomatidae) is slowly vanishing from the water habitats.

\section{Historical relevance of entomophagy}

Entomophagy means practice of eating insects, i.e. many animals such as spiders, lizards and birds are 
entomophagous. Some of the people around the world have been eating insects as a regular part of their food for millennia; this practice specified as human entomophagy (van Huis et al. 2013). The earliest evidences of entomophagy cited in biblical literature. Arthropods as a food is not new for human, especially crustaceans, i.e. crabs, lobster, prawns and shrimps. Chimpanzees, which are our closest living primate relatives, have ability to use tools to eat insects from their habitats and many of these tools are used to forage efficiently for edible insects. But farming of insects as food and feed not found in our history, but as exception they are utilized in many industries such as honey, silk and lac and some other for medicinal proposes.

Nearly 80 per cent of the world's population consumes insect as an intentional part of their diet (Costa-Neto and Dunkel, 2016). China has records of eating insects nearly back 3000 years, with regions in which people eat insects habitually (Chen, 1999; Feng and Chen, 2002). One of the studies reveals the availability of edible insect species throughout the world that reflected that 11 European countries, 14 countries in Oceania, 23 American countries, 29 Asian countries and 35 African counties, with Mexico, China, Thailand and India are the leading consumer countries and those with the most species (Jongema, 2017). Human entomophagy is practiced regularly by at least 2 billion people worldwide. Arunachal Pradesh is one the several regions where large numbers of insects viz., ant, Oecophylla smaragdina (Hymenoptera: Formicidae) and the termite, Odontotermes spp. (Isoptera: Termitidae) are still being used as food (Meyer-Rochow and Chakravorty, 2013).

\section{Current status of insect farming}

Insect farms had started since long before in 1940s after the Second World War in the United States. Some of the first cricket insect farms founded around 1945 in Glennville,
GA, USA. There are many insect species that are used as human food or as a feed for animals. There about 2100 species of insect those are used as a human food around the world (Jongema, 2017). The status of edible insect species comes under following orders are; Coleoptera: beetle's larvae $(31 \%)$, Lepidotpera: caterpillar (17\%), Hymenoptera: wasps, bees and ants (15\%), Orthoptera: crickets, grasshoppers and locusts (14\%), Hemiptera: true bugs $(11 \%)$, Isoptera: termites $(3 \%)$ and the dragonflies, flies and others (9\%). Insect species which are farmed for human consumption, mainly comes from mealworms (larvae of beetle family Tenebrionidae), crickets and grasshoppers and as for animal feed, they are black soldier fly (BSF) Hermetia illucens (Diptera: Stratiomyidae), housefly, Musca domestica (Diptera: Muscidae) and mealworms.

At international level, FAO is working on edible insects since 2003, to generate and share knowledge through publication, expert meetings, web portal and support many of the member countries through field projects, so that insect farming industry may boost up, so that in future food and nutritional security would be maintained. Now with some increasing research and development encouragement those insects have ability to supply sustainable level of nutrition, especially protein. The regulatory authorities of many countries are in the natal stage of framing legislative structures related to the use of insects for human consumption (Holloran, 2014). Investors have shown much interest in insect protein start-ups, the world's newest livestock industry, according to a Robobank analyst these new start-ups brought in $\$ 850$ million of investment in 2020 and in its report it is described that market is currently produces about 10,000 metric tonnes of protein annually and is expected to reach 500,000 metric tonnes by 2030 . Five insect species (Table 1) from the commercial point of view are given priority in the Korea (Kim and Jung, 2013).

Table 1: Preferred insects used as food and feed.

\begin{tabular}{lccccc}
\hline \multirow{2}{*}{$\begin{array}{l}\text { Scientific names } \\
\text { Order }\end{array}$} & \multicolumn{2}{c}{ Taxonomic position } & Life stage of & Primary \\
\cline { 2 - 5 } & Family & commercial interest & purpose & & Feed \\
\hline Allomyrina dichotoma & Coleoptera & Dynastidae & Larvae & Medicinal & Fermented saw dust \\
Protaetia brevitarsis & Coleopteran & Cetoniidae & Larvae & Medicinal & Fermented saw dust \\
Tenebrio molitor & Coleoptera & Tenebrionidae & Larvae & Food & Wheat bran and Chinese cabbage \\
Teleogryllus emma & Orthoptera & Gryllidae & Late nymph & Feed & Wheat bran and anchovies \\
Gryllus bimaculatus & Orthoptera & Gryllidae & Late nymph & Feed & Wheat bran and anchovies \\
\hline
\end{tabular}

Table 2: Examples of energy content of differently processed insects species.

\begin{tabular}{llc}
\hline Common Name & Scientific name & \multicolumn{1}{c}{$\begin{array}{l}\text { Energy content } \\
\text { (kcal/100 g fresh weight) }\end{array}$} \\
\hline Green ant, raw & Oecophylla smaragdna \\
Termite, adult, dewinged, dried, flour & Macrotermes subhyalinus & 535 \\
Australian plague locust, raw & Chortoicetes terminifera & 499 \\
Leaf-cutter ant, adult, raw & Atta mexicana \\
Yellow mealworm, larva, raw & Tenebrio molitor \\
Migratory locust,adult, raw & Locusta migratoria \\
Red legged grasshopper, whole, raw & Melanoplus femurrubrum \\
\hline
\end{tabular}


Table 3: Crude protein content, by insect order.

\begin{tabular}{lcr}
\hline Insect order & Stage & $\begin{array}{r}\text { Range } \\
(\% \text { protein })\end{array}$ \\
\hline Odonata & Adults and naid & $46-65$ \\
Hemiptera & Adult and larvae & $42-74$ \\
Homoptera & Adults, larvae and eggs & $45-57$ \\
Coleoptera & Adult and larvae & $23-66$ \\
Hymenoptera & Adults, pupae, larvae and eggs & $13-77$ \\
Lepidoptera & Pupae and larvae & $14-69$ \\
Orthoptera & Adults and nymphs & $23-65$ \\
\hline
\end{tabular}

\section{Insect farming}

There are efforts to promote the consumption of edible insect by human and they should be reared as mini-livestock. Insect are promoted as food and feed due to three important reasons, i.e. health, environmental and livelihood. Insects are healthy, nutritious alternatives to chicken, pork, beef and fish. They are rich source of protein and good fats, high in calcium, iron and zinc. At Oaxaca State, Mexico, Ramos Elorduy et al. (1997) analyzed 78 insect species to determine caloric content and it was 293-762 kcal per $100 \mathrm{~g}$ of dry matter (Table 2). Protein content in 100 species from a number of insect order were evaluated by Xiaoming et al. (2010), shows that protein content was in the range 13-77 percent of dry matter and variation between insect order were also seen (Table 3).

Environmentally, the production of animal products generates the majority of food related greenhouse gas (GHG) emission (72-78\% of the total agricultural emissions). The dietary changes are must in order to reduce the GHG emissions; insect species were considerably lower in GHG emissions than conventional livestock in their respiration and metabolism.

Rearing and harvesting of the insect is a low tech, lowcapital investment option even to poorest section of society, such as women and landless workers. Insects farming provide lowest cost proteins at $40-75 \mathrm{~g}$ per $100 \mathrm{~g}$ of dry weight of insects.

At present insect farming is in its natal stage; current insect farms are very small and have lack of technology and mechanization that the other farm. Mass production of insect at farm's affected by many diseases i.e. virus and fungus diseases. There are constraints in aspiring insect based food entrepreneurs, related food industries, consumers and there is lack of insect food legislations, regarding proper labeling, ingredients etc. Next generation will be entomophagy and for them the insect farm for mass rearing will be a general practice to feed. During mass rearing there may be some infectious disease in insects, therefore there is a need to educate the next generation about the insect pathology, as to be insect doctors. These insect doctors will provide new insights into the biology of pathogens in mass reared insects, they develop methods, technical skills and tools to diagnose and manage problems in commercial insect production systems.
Insects farming produce insects as feed that would be the good source in aquaculture to provide natural feed for fishes with correct amino acid profile. Insect as feed may replace the currently fed soy protein use in poultry with insect feed that benefits in welfare and resulting in higher body weight. Insect based food may be better for pests than prime steak. Recently, in Europe dried yellow mealworm larva (Tenebrio molitor) as novel food pursuant for human consumption to regulation (EU) 2015/2283 (Turck et al. 2021).

\section{CONCLUSION}

In tropical countries peoples are paying higher prices for harvesting of edible insects from nature and have led to overexploitation. Therefore, sustainable harvesting practices may be developed by assuring the future harvesting through insect farms, as mini-livestock. The farming of these edible insect uses as food and feed is solution as these require less land and water and emit less green house gases then the common livestock species. Edible insects farming production will be mainly on organic side and to make them easily available at low prices. This sector of insect as a food and feed is an emerging agricultural sector with a lot of potential to lower environmental impact.

Consumption of insect as a food in India have some religious and psychological related constraints i.e. disgust sensitivity, risks in consuming insects, tolerance or resistance to try new food. It's long to go with a majority of educational efforts to change consumer perception of insects a regular and good food choice with emphasis that insect as food is beneficial for environment, nutrition and health concern.

\section{REFERENCES}

Chen, X.O. (1999). The present situation and prospects of utilization of resource insects in China. World Forest Research. 1: 46-52.

Costa-Neto, E.M., Dunkel, F.V. (2016). Insects as Food: History, Culture and Modern Use around the World. In: Insects as Sustainable Food Ingredients, [(Eds) Aaron T. Dossey, Juan A. Morales-Ramos, M. Guadalupe Rojas], Academic Press, 2016, Pages 29-60, ISBN 9780128028568, https:/ /doi.org/10.1016/B978-0-12-802856-8.00002-8.

Dzamba, J. (2010). Third Millennium Farming: Is it time for another farming revolution? Architecture, Landscape and Design. Toronto, CA. Available from: http://www.thirdmillennium farming.com/.

FAO (2009). How to feed the world in 2050. http://www.fao.org/ fileadmin/templated/wsfs/docs/expert_paper/.pdf Accessed 15 Jan 2017.

Feng, Y. and Chen, X.M. (2002). Resources value of edible insects and utilizable ways. Forest Research. 15: 105-110.

Gerber, P. J., Steinfeld, H., Henderson, B., Mottet, A., Opio, C., Dijkman, J. (2013). Tackling climate change through livestock- A global assessment of emissions and mitigation opportunities. Rome: Food and Agriculture Organization of the United Nations (FAO). http://www.fao.org/3/ai3437e.pdf accessed 11 March 2019. 
Edible Insects a Novel Food Processing Industry: An Overview

Glavic, P. and Lukman, R. (2007). Review of sustainability terms and their definitions. Journal of Clean Production. 15: 1875-1885.

Halloran, A. (2014). Regulatory frameworks influencing insects as food and feed. www.fao.org/edible-insects/3962004eee142dbb758d9a521c619f31e Accessed 15 Dec 2016.

Jongema, Y. (2017). List of Edible insect species of the World. Laboratory of Entomology, Wageningen University, Netherlands. http://www.ent.wur.nl/UK/Ediblepinsects/ Worldwidepspeciesplist.

Kim, H.S. and Jung, C. (2013). Nutritional characteristics of edible insects as potential food materials. Korean Journal of Apiculture. 28: 1-8.

Meyer-Rochow, V.B., Chakravorty, J. (2013). Notes on entomophagy and entomotherapy generally and information on the situation in India in particular. Journal Applied Entomology and Zoology. 48: 105-112.

Radhika, P. and Subbaratnam, G.V. (2006). Insecticide resistance management in cotton-Indian scenario- A review. Agricultural Reviews. 27: 157-169.

Ramos Elorduy, J. (1997). The importance of edible insects in the nutrition and economy of people of the rural areas of Mexico. Ecology of Food and Nutrition. 36: 347-366.
Safina, C. (2011). Why Are We Using Up the Earth? CNN Opinion: Carbon Dioxide. CNN, New York, NY.

Smetana, S., Mathys, A., Knoch, A., Heinz, V. (2015). Sustainability of meat substitutes: a path to future foods? In: $29^{\text {th }}$ EFFoST International Conference Proceedings, pp. 126-131.

Turck, D., Castenmiller, J., De Henauw, S., Hirsch-Ernst, K.I., Kearney, J., Maciuk, A., Mangelsdorf, I., et al. (2021). Scientific opinion on the safety of dried yellow mealworm (Tenebrio molitor larva) as a novel food pursuant to Regulation (EU). EFSA Journal. 19(1): 29pp.

Van Huis, A., Van Itterbeeck, J., Klunder, H., Mertens, E., Halloran, A., Muir, G., Vantomme, P. (2013). Edible Insects: Future Prospects for Food and Feed Security. FAO Forestry Paper 171. Food and Agriculture Organization of the United Nations, Rome.

Xiaoming, C., Ying, F., Hong, Z., Zhiyong, C. (2010). Review of the Nutritive Value of Edible Insects. In: Forest Insects as Food: Humans Bite Back, [(Eds) P.B. Durst, D.V. Johnson, R.L. Leslie. and K. Shono], Proceedings of a Workshop on Asia-Pacific Resources and Their Potential for development. Bangkok, FAO Regional Office for Asia and the Pacific. 